\title{
Revisiting the paper on "Applications of graph theory to enzyme kinetics and protein folding kinetics: steady and non-steady state systems" (Short Communication)
}

\section{Kuo-Chen Chou}

Gordon Life Science Institute, Boston, Massachusetts 02478, USA.

Corresponding Author: Kuo-C. Chou (2020) Gordon Life Science Institute, Boston, Massachusetts 02478, USA.

Received date: November 18, 2020; Accepted date: November 30, 2020; Published date: December 23, 2020

Citation: Kuo-Chen Chou (2020) Revisiting the paper on "Applications of graph theory to enzyme kinetics and protein folding kinetics: steady and non-steady state systems" J, Biotechnology and Bioprocessing 1(3); DOI: 10.31579/2766-2314/012

Copyright: (C) 2020, Kuo-Chen Chou, This is an open access article distributed under the Creative Commons Attribution License, which permits unrestricted use, distribution, and reproduction in any medium, provided the original work is properly cited.

\section{Short Communication}

About 30 years ago a very important paper on "Applications of graph theory to enzyme kinetics and protein folding kinetics: steady and nonsteady state systems" was published [1].

Ever since then, a series of papers for graph theory to study enzyme kinetics [2-8] and protein folding kinetics [9-15].

The graph approach can provide an intuitive feeling for analyzing very complicated biological systems, as clearly demonstrated in the eight masterpieces papers [16-23] by the then Chairman of Nobel Prize Committee.

\section{References}

1. K.C. Chou, (1990) Review: Applications of graph theory to enzyme kinetics and protein folding kinetics. Steady and nonsteady state systems, Biophysical Chemistry, 35, 1-24.

2. I.W. Althaus, J.J. Chou, A.J. Gonzales, M.R. Diebel, K.C. Chou, et al (1993) Steady-state kinetic studies with the non-nucleoside HIV-1 reverse transcriptase inhibitor U-87201E, J. Biol. Chem., 268, 6119-6124.

3. I.W. Althaus, J.J. Chou, A.J. Gonzales, M.R. Diebel, K.C. Chou, et al (1993) Kinetic studies with the nonnucleoside HIV-1 reverse transcriptase inhibitor U-88204E, Biochemistry, 32, 6548-6554.

4. I.W. Althaus, A.J. Gonzales, J.J. Chou, M.R. Diebel, K.C. Chou, et al (1993) The quinoline U-78036 is a potent inhibitor of HIV-1 reverse transcriptase, J. Biol. Chem., 268, 14875-14880.

5. I.W. Althaus, J.J. Chou, A.J. Gonzales, M.R. Diebel, K.C. Chou, et al (1994) Steady-state kinetic studies with the polysulfonate U9843, an HIV reverse transcriptase inhibitor, Cellular and Molecular Life Science (Experientia), 50, 23-28.

6. I.W. Althaus, J.J. Chou, A.J. Gonzales, M.R. Diebel, K.C. Chou, et al (1994) Kinetic studies with the non-nucleoside human immunodeficiency virus type-1 reverse transcriptase inhibitor $\mathrm{U}$ 90152e, Biochem. Pharmacol., 47, 2017-2028.

7. K.C. Chou, F.J. Kezdy, F. Reusser, (1994) Review: Kinetics of processive nucleic acid polymerases and nucleases, Anal. Biochem., 221, 217-230.
8. I.W. Althaus, K.C. Chou, K.M. Franks, M.R. Diebel, F.J. Kezdy, et al (1996) The benzylthio-pyrididine U-31,355, a potent inhibitor of HIV-1 reverse transcriptase. Biochem. Pharmacol., 51, 743-750.

9. L. Carlacci, K.C. Chou, (1990) Energetic approach to the folding of four a-helices connected sequentially, Protein Eng., 3, 509-514

10. K.C. Chou, L. Carlacci, (1991) Energetic approach to the folding of alpha/beta barrels, Proteins: Struct., Funct., Genet., 9, 280-295.

11. K.C. Chou, (1993) Mini Review: Prediction of protein folding types from amino acid composition by correlation angles, Amino Acids, 6, 231-246.

12. K.C. Chou, (1993) Graphic rule for non-steady-state enzyme kinetics and protein folding kinetics. $J$ of Mathematical Chemistry, 12, 97-108.

13. K.C. Chou, C.T. Zhang, (1993) A new approach to predicting protein folding types, J. Protein Chem., 12, 169-178.

14. K.C. Chou, C.T. Zhang, (1994) Predicting protein folding types by distance functions that make allowances for amino acid interactions, J. Biol. Chem., 269, 22014-22020.

15. K.C. Chou, (1995) Does the folding type of a protein depend on its amino acid composition?, FEBS Lett., 363, 127-131.

16. K.C. Chou, S. Forsen, (1980) Diffusion-controlled effects in reversible enzymatic fast reaction system: Critical spherical shell and proximity rate constants, Biophysical Chemistry, 12, 255-263.

17. K.C. Chou, S. Forsen, (1980) Graphical rules for enzymecatalyzed rate laws, Biochem. J., 187, 829-835.

18. K.C. Chou, S. Forsen, G.Q. Zhou, (1980) Three schematic rules for deriving apparent rate constants, Chemica Scripta, 16, 109113.

19. K.C. Chou, T.T. Li, S. Forsen, (1980) The critical spherical shell in enzymatic fast reaction systems, Biophysical Chemistry, 12, 265-269.

20. T.T. Li, K.C. Chou, S. Forsen, (1980) The flow of substrate molecules in fast enzyme-catalyzed reaction systems, Chemica Scripta, 16,192-196.

21. K.C. Chou, R.E. Carter, S. Forsen, (1981) A new graphical method for deriving rate equations for complicated mechanisms, Chemica Scripta, 18, 82-86. 
22. K.C. Chou, N.Y. Chen, S. Forsen, (1981) The biological functions of low-frequency phonons: 2. Cooperative effects, Chemica Scripta, 18, 126-132.

23. K.C. Chou, S. Forsen, (1981) Graphical rules of steady-state reaction systems, Can. J. Chem., 59, 737-755. 